\title{
Assessment of Pesticide Residues in Some Commonly Cultivated Vegetables in Doma Metropolis, Nasarawa State, Nigeria
}

\author{
Abdullahi, A.E. ${ }^{1}$; Aguoru, C. U. ${ }^{1}$, Ogbonna I.O. ${ }^{1}$; Olasan, J.O. ${ }^{1}$ and Umar, N.D. ${ }^{2}$ \\ ${ }^{1}$ Environmental Science, Biotechnology and Genetics Unit, Department of Botany, Federal University of Agriculture, Markudi \\ Benue State, Nigeria. \\ ${ }^{2}$ Department of Geology, Federal University Lafia Nasarawa state, Nigeria \\ Corresponding author: Abdullahi, A.E.
}

\begin{abstract}
Commonly cultivated vegetables (Amaranthus hybridus, and Corchorus olitorius) in Doma and environs were analyzed to determine the residual level of pesticide. The samples extracts were subjected to High Performance Liquid Chromatography (HPLC) using Acetonitrile, Anhydrous $\mathrm{MgSO}, \mathrm{NaCl}$ and Ultrapure water used as mobile phase. Data obtained were analyzed using Minitab 16.0.The following tests were applied: Chi square test of association, Mann Whitney U-test of comparing two non parametric systems, Kruskal Wallice H-test and the Independent t-test of significance. All hypotheses were tested at $95 \%$ level of significance. Analysis showed highest concentrations residual level of Cypermethrin in the Doma wet Corchorus olitorius sample at $2240.94 \mathrm{mg} / \mathrm{L}$ with no traces in Igbabo sample. For the dry Corchorus olitorius sample, highest value was recorded in Doma (61.046mg/l) while Igbabo sample showed the lowest $(9.285 \mathrm{mg} / \mathrm{l})$. The highest residual value $(226.39 \mathrm{mg} / \mathrm{l}$.) of Cypermethrin in Amaranthus hybridus appeared at Igbabo with the lowest (12.18mg/l) in Alwaza Lamda Cyhalothrin, Alwaza wet Corchorus olitorius sample recorded highest value of $0.00593 \mathrm{mg} / \mathrm{l}$ with lowest value $(0.00058 \mathrm{mg} / \mathrm{l})$ in Doma. Dry sample jute recorded highest $(0.0159 \mathrm{mg} / \mathrm{l})$ in Igbabo; lowest value $(0.0002 \mathrm{mg} / \mathrm{l})$ in Doma. In spinach samples, the highest value $(0.00171 \mathrm{mg} / \mathrm{l})$ appeared in Alwaza while igbabo $(0.00051 \mathrm{mg} / \mathrm{l})$ recorded the lowest. The results showed that Cypermethrin values were well above the Japan Research Foundation MRLs of 0.03mg/l. This has serious implications on the consumers of the vegetables cultivated in the study area. However, for Lamda Cyhalothrin residues results occurred on levels well below MRLs of $0.5 \mathrm{mg} / \mathrm{l}$.
\end{abstract}

Keywords-Health Risk, Jute, Pesticide, Residue, and Vegetables.

\section{INTRODUCTION}

Pesticide is an umbrella for all insecticide, herbicides, fungicides, rodenticides, wood preservatives, garden chemicals and household disinfectants that may be used to kill some pest [10]. Pesticides are mostly man-made chemicals agents use to control insects, weeds, fungi and other pests that destroy crops [17] [23]. Different kind of pesticides are used for pest management and vector control in agricultural farms, even though many farming communities are not adequately informed about the hazards associated with the chemicals [26]. Pesticide has considerably help to reduce loses and gives a better yield in agricultural produce [4]. Therefore, knowledge on the use of pesticide is considered to be a fundamental factor in maintaining high agricultural productivity [26]. However, reliance on pesticide is difficult to sustain due to adverse effect on the environment. As a result to their high degree of toxicity, most pesticides are harmful to both human and the environment [13]. Although pesticides are manufactured under very strict regulations processes to function with logical certainty and minimal impact, excessive application of these pesticide results into bioaccumulation of its residues [19]. Pesticide residues are the deposit of the active constituent. Its metabolites or breakdown products are present in some component of the environment after its application, spillage or dumping [25].

More than a few reports show that the usage of pesticide has increased significantly during the last three decades consequent with changes in farming practices and the increasing intensive agriculture. This extensive use of pesticides has resulted in the presence of their residues in various environmental matrices, especially food stuff proving the high risk of these chemicals to human health and the environment. Studies have shown that vegetable 
intake is positively related in urinary metabolites levels of pyrethroid pesticides [20]. Other hazardous pesticide is Organochlorines pesticides and are the most persistent class of these pesticides; however, due to their adverse effects on human health and the environment, they have been banned in most countries [23].

In Nigeria, Vegetable farmers use a wide range of pesticides at different levels to reduce losses from pest and diseases. However, despite the contribution of pesticide to agricultural production, evidences in other studies showed presence of pesticide residues that could be detrimental to human health and the ecosystems [26]. Among the traditional vegetables in Nigeria are Amaranthus hybridus (spinach) Corchorus olitorius (Jute), Talinum Triangulare (water leave), Telfairia occidentalis (ugu.). Most of these vegetables are consumed in the rural areas or in the communities where they are being planted and sold in the open markets [3]. Nowadays, most vegetables are grown all over the world as climate permits, [15]. Pesticide residues most commonly found in food samples of vegetable farms are pesticides that are intentionally applied to the plants to attack pests and plant diseases [21]. When these pesticides are applied to destroy pests and pathogens, only $15 \%$ of the applied amount hits the target, with the remaining 85\% being distributed in soils and air [11]. Also, the improper implementations of hazardous chemicals and pesticide regulations and lack of awareness on technical knowhow among the farming communities leaves most of the pesticides active ingredients in vegetables. The present study aimed to investigate and determine pesticide residues in commonly cultivated vegetables grown in three selected communities (Alwaza, Doma, and Igbabo) of Doma Local government Area of Nasarawa state, Nigeria.

\section{MATERIALS AND METHODS}

\section{Description of the Study Area}

The study area Doma metropolis, is located in the North central Nigeria, it is marked by dry season from the month of November to May. Rainfall is mostly conventional type caused by persisting heating of land air mass. The months of December to February are characterized by slight cold harmattan, while March- April hottest period with temperature above $30^{\circ} \mathrm{C}$. It covers an area of $2726 \mathrm{sq} \mathrm{kms}$ with an estimated population of over 98,803 people (2006 census).

\section{Samples collection}

To determine the residual pesticides in the vegetables of the study area, fresh samples of vegetables (Amarathus hybridus and Corchorus olitorius) were collected from the three communities' farms randomly; Alwaza (8022'40.88'’ N 008023'06.79'E), Igbabo $\quad\left(08^{0} 12^{\prime} 36.69^{\prime \prime} \mathrm{N}\right.$ $\left.008^{0} 17^{\prime} 55.60^{\prime \prime} \mathrm{E}\right) \quad$ and Doma $\left(08^{0} 23^{\prime} 42.09^{\prime \prime} \mathrm{N}\right.$ $\left.008^{0} 2119.81^{\prime \prime} \mathrm{E}\right)$. The vegetables samples were taken in plastic bags at room temperature to Chemistry Advance Research Center, Sheda Science and Technical Complex (SHESTCO) km 10 Kwali -Abuja Road Gwagwalada for analysis.

\section{Reagents and materials}

Residues of pesticides were determined in two types of vegetables samples by using High Performance Thin Layer Chromatography (HPLC). Analytical-grade (BEST and ATTAKE) pesticides standard were ordered from certified seller for the standard solution in liquid form. $1 \%$ solution of the standard was prepared. Acetonitrile of HPLC grade was purchased from FINLAB. Deionized water, dimethyl formamide; anhydrous magnesium sulfate, $500 \mathrm{ml}$ Erlenmeyer flask was selected and Primary Secondary Amine (PSA)-bonded silica were used for the sample preparation procedure. Anhydrous $\mathrm{MgSO} 4$, and $\mathrm{NaCl}$ were obtained from Sheda Science and Technical Complex (SHESTCO) Ultrapure water was used as mobile phase, which were filtered through a $0.45 \mathrm{~mm}$ polyvinylidene difluoride (PVDF) filter before injection. Standard stock solution was prepared by dissolving the liquid standard in acetonitrile to reach the final concentration of 1000 to 4000 $\mathrm{mg} / \mathrm{ml}$. For method optimization, standard solutions were used, which were prepared by diluting the stock solution to a concentration of 1 to $4 \mathrm{mg} / \mathrm{ml}$. A standard mix solution in acetonitrile for preparation of calibration standards was prepared to yield $10 \mathrm{mg} / \mathrm{ml}$.

\section{Sample preparation}

For the detection of Cypermethrin concentrations in the samples, the acetate-buffered sample preparation method for pesticides (AOAC Official Method 2007.01) was applied to all the samples. After homogenization with a house-hold (equipped with stainless steel knives). $10 \mathrm{~g}$ of the well-chopped, homogenized sample was weighed into a $40 \mathrm{~mL}$ polypropylene (PP) centrifuge tube followed by addition of $10 \mathrm{~mL}$ of acetonitile and shaking the sample vigorously for approximately 1 minute. Next, an addition of $4 \mathrm{~g}$ anhydrous $\mathrm{MgSO} 4$ and $1 \mathrm{~g} \mathrm{NaCl}$ is followed by intense agitation. Afterwards, a $1 \mathrm{~mL}$ aliquot of the upper 
acetonitrile layer is transferred into a centrifuge vial containing $25 \mathrm{mg}$ of PSA sorbent and $150 \mathrm{mg}$ of anhydrous MgSO4. Then, the sample is shaken by hand or with the vortex mixer for 30 seconds and centrifuged. The obtained supernatant is taken from the centrifuge vial and as a final extract can be analyzed directly using LC-techniques coupled with mass spectrometry detectors. To determine the concentration of Lamda Cyhalotrhrin in the vegetable samples, approximately $10 \mathrm{~g}$ of each sample was also weighed and macerated and $10 \mathrm{ml}$ of water-methanol (50/50) was added. It was soaked overnight. The filtrate was partitioned with $10 \mathrm{ml}$ acetone- hexane and the hexane layer was collected into a sample bottle. HPLC analys is Mobile phase: Acetonitrile/water (20/80 v/v) Wavelength $250 \mathrm{~nm}$ Flow rate: $1 \mathrm{ml}$ per mins; sample injected $20 \mu 1$

\section{High Performance Liquid Chromatographic (HPLC) Analysis}

Extracted samples of vegetables were analyzed by high performance liquid chromatography (HPLC) following the method of [16] HPLC analyses were performed in isocratic system using a PerkinElmer Chromatograph including Series 200 pump, Series 200 UV/VIS detector, and a Supelco C18 analytical column $(25 \mathrm{~cm} \times 4.6 \mathrm{~mm}$ (i.d)). Acetonitrile/water was used as mobile phase. $20 \mu 1$ sample was injected through auto sampler. The column temperature was kept $30^{\circ} \mathrm{C}$ with a flow rate of $1 \mathrm{ml}$ min-1.

\section{Statistical analysis}

Data obtained from structured questionnaires were collated and entered into Microsoft Excel Workbook (2010 version). Descriptive statistical operations were applied using frequency counts, percentages, tabulations pie chart and bar chart. Data obtained from quantification of pesticides in plant samples were analyzed using Minitab 16.0. Appropriate unit conversions were done to ensure uniformity. The following tests were applied: Chi square test of as sociation, Mann Whitney U-test of comparing two non parametric systems, KruskalWallice H-test as a non parametric One-way ANOVA analog and the Independent ttest of significance. All hypotheses were tested at $95 \%$ level of significance

\section{RESULTS AND DISCUSSION}

Table 1 presents the quantity of Cypermethrin found in wet jute plant. The Control wet Jute plant had $0.00 \mathrm{mg} / \mathrm{L}$ of Cypermethrin. At Igbabo, the concentration of this pesticide was also $0.00 \mathrm{mg} / \mathrm{L}$. Wet Jute at Doma had $2240.94 \mathrm{mg} / \mathrm{L}$ of Cypermethrin. About $29.22 \mathrm{mg} / \mathrm{L}$ of the pesticide was found in the Alwaza jute sample. Significant association exists between Jute sample location and quantity of Cypermethrin found $\left(\chi^{2}=6579.73, \mathrm{P}=0.000\right)$. Table 2 gives the quantity of Cypermethrin in dry jute plant. The control dry sample had $1.753 \mathrm{mg} / \mathrm{L}$ of Cypermethrin. Quantities of this pesticide found in all other samples were higher than the control samples as stated in order of magnitude: Doma jute $(61.05 \mathrm{mg} / \mathrm{L})$, Alwaza jute $(58.96 \mathrm{mg} / \mathrm{L})$ and Igbabo jute $(9.29 \mathrm{mg} / \mathrm{L})$. Significant association exists between quantity of cypermethrin and the dry jute sample collected from different locations $\left(\chi^{2}=91.5468, \quad \mathrm{P}=0.000\right)$.

Table 3 compares Cypermethrin level in wet and dry jute samples. No particular pattern of relationship was established in the pesticide level in the wet and dry samples across the locations. At Igbabo, cypermethrin level was nil in wet jute whereas the dry type recorded $9.285 \mathrm{mg} / \mathrm{L}$ of the pesticide. At Doma, the wet jute had skyrocketed level of $2240.94 \mathrm{mg} / \mathrm{L}$ far higher than the $61.05 \mathrm{mg} / \mathrm{L}$ of the dry sample. At Alwaza, the dry state had higher level of the pesticide than the wet state. Hence, Mann Whiteney U test recorded significant differences in the level of Cypermethrin in wet and dry jute sample depending on the location $(\mathrm{U}=16.0, \mathrm{P}<0.05)$.

Table 4 gives the quantity of cypermethrin found in spinach in different locations. The control spinach had zero level of cypermethrin. Igbabo spinach had the highest level of the pesticide with $226.39 \mathrm{mg} / \mathrm{L}$ followed by Doma spinach with $135 \mathrm{mg} / \mathrm{L}$ and Alwaza spinach with $12.18 \mathrm{mg} / \mathrm{L}$ of cypermethrin. Significant association exists between cypermethrin level and the locations of spinach samples $\left(\chi^{2}\right.$ $=371.880 \mathrm{P}=0.000)$. Table 5 compares cypermethrin level in wet jute and spinach across different locations. Cypermethrin contents were higher in wet jute collected from Doma and Alwaza than in spinach samples collected from the same locations. However, the Igbabo spinach had $226.39 \mathrm{mg} / \mathrm{L}$ of cypermethrin whereas the Igbabo wet jute did not contain cypermethrin. Mann-Whitney U test showed significant differences in pesticide levels in wet jute and spinach sample $(\mathrm{U}=17.0, \mathrm{P}<0.05)$. 
Table:1 Quantity of Cypermethrin in Wet Jute (Corchorusolitorius)

\section{Sample}

Sample

Wet Jute (Igbabo)

Wet Jute (Doma)

Wet Jute (Alwaza)

Wet Jute (Control)

\section{Quantity of Cypermethrin Pesticide}

(mg/L)

0.00

2240.94

29.22

0.00

$\chi^{2}=6579.73, \quad \mathrm{P}=0.000 \quad(\mathrm{P}<0.05)$

Table 2: Quantity of Cypermethrin in Dry Jute (Corchorusolitorius)

\begin{tabular}{cc}
\hline Sample & Quantity of Cypermethrin Pesticide (mg/L) \\
\hline Dry Jute (Igbabo) & 9.285 \\
Dry Jute (Doma) & 61.046 \\
Dry Jute (Alwaza) & 58.964 \\
Dry Jute (Control) & 1.753 \\
\hline
\end{tabular}

$\chi^{2}=91.5468, \quad \mathrm{P}=0.000 \quad(\mathrm{P}<0.05)$

Table 3: Comparison of Cypermethrin Level in Wet and Dry Jute Samples (Corchorusolitorius)

\begin{tabular}{ccc}
\hline Location & $\begin{array}{c}\text { Cypermethrin in Wet Jute } \\
(\mathbf{m g} / \mathbf{L})\end{array}$ & $\begin{array}{c}\text { Cypermethrin in Dry Jute } \\
(\mathbf{m g} / \mathbf{L})\end{array}$ \\
\hline Igbabo & 0.00 & 9.285 \\
Doma & 2240.94 & 61.046 \\
Alwaza & 29.22 & 58.964 \\
Control & 0.00 & 1.753 \\
\hline
\end{tabular}

$\mathrm{U}=16.0, \mathrm{P}<0.05$

Table: 4 Quantity of Cypermethrin in Spinach (Amaranthus)

\begin{tabular}{rcc}
\hline Sample & $\begin{array}{c}\text { Quantity of Cypermethrin Pesticide } \\
(\mathbf{m g} / \mathbf{L})\end{array}$ \\
\hline Spinach (Igbabo) & 226.39 \\
Spinach (Doma) & 135.69 \\
Spinach (Alwaza) & 12.18 \\
Spinach (Control) & 0.00 \\
\hline
\end{tabular}

$\chi^{2}=371.880 \quad \mathrm{P}=0.000(\mathrm{P}<0.05)$

Table 5: Comparison of Cypermethrin Level in Wet Jute and Wet Spinach

\begin{tabular}{ccc}
\hline Location & $\begin{array}{c}\text { Cypermethrin in Wet Jute } \\
(\mathbf{m g} / \mathbf{L})\end{array}$ & $\begin{array}{c}\text { Cypermethrin in Wet Spinach } \\
(\mathbf{m g} / \mathbf{L})\end{array}$ \\
\hline Igbabo & 0.00 & 226.39 \\
Doma & 2240.94 & 135.69 \\
Alwaza & 29.22 & 12.18 \\
Control & 0.00 & 0.00 \\
\hline
\end{tabular}

$\mathrm{U}=17.0, \mathrm{P}<0.05$

Table 6 presents the quantity of lamdacyhalothrin in wet jute samples obtained from different sites. Lambacyhalothrin levels were generally diminutive in wet juice across plant samples. It ranged from $0.00003 \mathrm{mg} / \mathrm{L}$ in Alwaza wet Jute to $0.00593 \mathrm{mg} / \mathrm{L}$ in control wet jute being higher than other samples. Based on KruskalWallice H-test, 
no significant differences exist in the pesticide level of the samples analysed $(\mathrm{H}=3.00, \mathrm{P}=0.392)$. As presented in Table 7, the quantities of lamdacyhalothrin in dry jute samples are diminutive and insignificant across samples $(\mathrm{H}$ $=3.00, \mathrm{P}=0.392$ ). It ranged from $0.00001 \mathrm{mg} / \mathrm{L}$ in Alwaza dry jute to 0.00159 in Igbabo dry jute. The control level $(0.00108 \mathrm{mg} / \mathrm{L})$ was higher than two samples but lower than the Igbabo dry jute.

Lamdacyhalothrin contents in spinach samples were also diminutive and low (Table 8). The control sample had higher pesticide content $(0.00171 \mathrm{mg} / \mathrm{L})$ than other samples in Doma $(0.00121 \mathrm{mg} / \mathrm{L})$ and in Igbabo $(0.00051 \mathrm{mg} / \mathrm{L})$. The Alwaza spinach had no trace of lamdacyhalothrin. No significant differences exist in the pesticide levels of the various samples analysed $(\mathrm{H}=3.0, \mathrm{P}=0.392)$. Table 9 compared lamdacyhalothrin contents of wet jute and spinach despite the diminutive level. In both plant types, the control levels were higher than other samples. In Igbabo, pesticide was higher in wet jute $(0.00104 \mathrm{mg} / \mathrm{L})$ than in spinach $(0.00051 \mathrm{mg} / \mathrm{L})$. In Doma, the level was higher in spinach $(0.00121 \mathrm{mg} / \mathrm{L})$ than in wet jute $(0.00058 \mathrm{mg} / \mathrm{L})$. In Alwaza, no trace of the pesticide in spinach whereas wet jute had very slight amount $(0.00003 \mathrm{mg} / \mathrm{L})$. Statistically, no significant differences exist in the lambacyhalothrin content in the two plant types (wet jute and spinach) as obtained from various sites $(\mathrm{T}=0.73, \mathrm{P}=0.516)$.

Table: 6 Quantity of LamdaCyhalothrin in Wet Jute (Corchorusolitorius)

\begin{tabular}{cc}
\hline Sample & $\begin{array}{c}\text { Quantity of LamdaCyhalothrin Pesticide } \\
(\mathbf{m g} / \mathbf{L})\end{array}$ \\
\hline Wet Jute (Igbabo) & 0.00104 \\
Wet Jute (Doma) & 0.00058 \\
Wet Jute (Alwaza) & 0.00003 \\
Wet Jute (Control) & 0.00593 \\
\hline
\end{tabular}

KruskalWallice $\mathrm{H}=3.00, \mathrm{P}=0.392(\mathrm{P}>0.05)$

Table 7: Quantity of LamdaCyhalothrin in Dry Jute (Corchorusolitorius)

\begin{tabular}{cc}
\hline Sample & $\begin{array}{c}\text { Quantity of LamdaCyhalothrin Pesticide } \\
(\mathbf{m g} / \mathbf{L})\end{array}$ \\
\hline Dry Jute (Igbabo) & 0.00159 \\
Dry Jute (Doma) & 0.00020 \\
Dry Jute (Alwaza) & 0.00001 \\
Dry Jute (Control) & 0.00108 \\
\hline
\end{tabular}

KruskalWallice $\mathrm{H}=3.00, \mathrm{P}=0.392(\mathrm{P}>0.05)$

Table 8: Quantity of LamdaCyhalothrin in Spinach (Amaranthus)

\begin{tabular}{cc}
\hline Sample & $\begin{array}{l}\text { Quantity of LamdaCyhalothrin Pesticide } \\
(\mathbf{m g} / \mathbf{L})\end{array}$ \\
\hline Spinach (Igbabo) & 0.00051 \\
Spinach (Doma) & 0.00121 \\
Spinach (Alwaza) & 0.00000 \\
Spinach (Control) & 0.00171 \\
\hline
\end{tabular}

$\mathrm{H}=3.0, \mathrm{P}=0.392(\mathrm{P}>0.05)$

Table 9: Comparison of LamdaCyhalothrin in Wet Jute and Spinach

\begin{tabular}{ccc}
\hline Location & $\begin{array}{c}\text { LamdaCyhal othrin } \\
(\mathbf{m g} / \mathbf{L})\end{array}$ & $\begin{array}{c}\text { LamdaCyhal othrin in Wet Jute } \\
\text { Spinach }(\mathbf{m g} / \mathbf{L})\end{array}$ \\
\hline Igbabo & 0.00104 & 0.00051 \\
Doma & 0.00058 & 0.00121 \\
Alwaza & 0.00003 & 0.00000 \\
Control & 0.00593 & 0.00171 \\
\hline
\end{tabular}

$\mathrm{T}=0.73, \mathrm{P}=0.516(\mathrm{P}>0.05)$ 


\section{DISCUSSION}

The study revealed excessive applications of the pesticides within the life cycle of the vegetables attributing to the high percentage of residual content in the vegetables. Our study was in agreement to research done by [16]. Also in the research by [26], it was revealed that the effects of pesticide exposure even for a short duration has the possibility of cumulative effects which farmers are themselves unaware of the health hazards associated with it. The detected cypermethrine residues in wet jute plant from the two communities (Doma and Alwaza) were above MRLs as prescribed by FAO/WHO. In all the three communities of the study area, the dry jute samples showed concentrations of cypermethrin residues ranges from $9.285 \mathrm{mg} / \mathrm{L}$ $61.046 \mathrm{mg} / \mathrm{L}$. The study also showed that the concentrations of cypermethrin in Doma wet jute was higher than the dry sample whereas the Alwaza dry jute sample was higher than the wet sample. The findings had similarity with researched by [16] which established that the levels of cypermethrin and lamda cyhalothrin residue in vegetables were above their respective MRLs values. Consequently, this work has confirmed the work of [16] regarding the observation that some pesticide residue in vegetables are above the MRLs. Similarly, [13] experimented on Cabbage, collected samples from different markets cape coast Ghana to assess the pesticide residues in the vegetable. The detected Cypermethrin and Lamda Cyhalothrin were below the residues detected in this research work. Unlike the study by [9] which indicated that Lamda Cyhalothrin was the most used pesticide in the control of pest in vegetable farms, in this study majority of the farmers applied Cypermethrin.

Also in the study by [17] Cypermethrin residue was determined in high concentrations when compared with other pesticides. This collaborated with this study where Cypermethrin residues in the selected vegetable samples were higher than the concentrations of lamda Cyhalothrin. As a result of these, the high level of the residues in the study suggested that pesticides were applied in excess; it is therefore plausible to state that farmers were not following proper precautions with regards to the use of pesticide in appropriate dosages and standards attributing to lack of training. The results also showed that cypermethrin residues in almost all the spinach samples were high in concentration which is in agreement with [16], who found out that cypermetrhin residues were found higher in almost all the vegetables analyzed.

Previous work done by [18] showed that Lamda Cyhalothrin was widely used on vegetables farms because of their effectiveness. The level of residues detected in this work was lower compared to [18]. Also the result from the study showed that Lamda Cyhalothrin residues were diminutive in wet juice across plants samples of the three communities of the study area. The low levels of the residue could be due to minimal usage of the pesticide by farmers and the unavailability of the products in the market. The result collaborated with [16] [13] research on cabbage, where lamda cyhalothrin residues detected was lowest in concentrations when compared to Cypermethrin residues. Also the findings in this study indicated diminutive and insignificant values across both wet and dry jute plants samples ranging from 0.00020 to $0.00159 \mathrm{mg} / \mathrm{l}$. In the spinach samples, the study showed little value of lamda cyhalothrin across the plant samples. The residues range from 0.00051 to $0.00171 \mathrm{mg} / \mathrm{L}$. The study showed slight variations of Lamda cyhalothrin in wet jute and spinach samples. The concentrations of lamda cyhalothrin residues in both wet jute and spinach of Alwaza sample were higher than Doma and Igbabo. Although pesticide helps to protect our vegetables during growth, however they may remain in or on foods as small amount after applications. In general the excessive applications of cypermethrin and lamda cyhalothrin in vegetables farms indicated high concentrations of residues when compared with other studies; these imply that there is increase trend in Nigeria about pesticide usage which can lead to significant health problems.

\section{CONCLUSION}

The two vegetables studied contained residues of Cypermethrin pesticide in high concentrations when compare to Lamda Cyhalothrin pesticides mostly detected above MRLs. This calls for strict implementation of regulations and proper monitoring by relevant stakeholders. Public enlightenment and training of farmers also by relevant agencies and nongovernmental organizations is necessary to reduce the hazards associated with excessive applications of pesticide in vegetables as these may affect the food chain. The need for possible alternative to agro chemicals rather than applications of pesticides in vegetables should be encouraged so that the extent of pesticide damage on public health and the environment could be regulated.

\section{REFERENCES}

[1] Aban, A. F., Kouamé, C. M., Abang, M., Hanna, A. K., and Fotso, R.(2014) Assessing Vegetable Farmer 
Knowledge of Diseases and Insect Pests of Vegetable and Management Practices Under Tropical Conditions International Journal of Vegetable Science ISSN: 1931-5260

[2] Abubakar, S., Ogbadu, G.H., Usman, A.B., Segun, O., Olorode, O., Samirah, I.U. (2012) The underutilized vegetable plants of the federal capital territory (FCT) Abuja of Nigeria International Journal of Development and Sustainability Online.

[3] Adeleke, R. O., and Abiodun, O. A. (2010) Chemical Composition of Three Traditional Vegetables in Nigeria Pakistan Journal of Nutrition (9): 858-860

[4] Akan, J. C., Jafiya, L., Mohammed, Z. and Abdulrahman, F. I. (2013) Organophosphorus pesticide residues in vegetables and soil samples from Alau Dam and Gongulong agricultural areas, Borno State, Nigeria International Journal of Environmental Monitoring and Analysis 12 : 58-64

[5] Ajiboye, A. A., Fadimu, O. Y., Ajiboye, M. D., Agboola, D. A., Adelaja, A. B., \& Bem, A.A. (2014) Phytochemical and Nutritional Constituents of Some Common Vegetables in South-West, Nigeria Global Journal of Science Frontier Research: C Biological Science Volume 14 Issue 3 Version 1.0

[6] Anam, M., and Syed, W. H. (2013) Quantification of Pesticide Residues in Vegetables by Different Chromatographic Techniques Punjab Forensic Science Agency, Pakistan

[7] Anzene, J.S., Tyohemba, R.L., Ahile, U.J., Emezi, K.S.A. (2014) Organochlorine pesticide residues analysis of postharvest cereal grains in Nasarawa State, Nigeria International Journal of Agronomy and Agricultural Research (IJAAR).

[8] Babarinsa, S. O., Ayoola, O., Fayinminnu, O. O., and Adedapo, A. A. (2018) Assessment of the Pesticides Usage in Selected Local Government Areas in Oyo State, Nigeria Journal of Experimental Agriculture International ISSN: 2457-0591, vol. 21 (1), pp. 1-13.

[9] Chionyedua, T. O., Anuoluwa M. O., and Adedoja, D. W. (2009) The proximate and mineral composition of three leafy vegetables commonly consumed in Lagos, Nigeria African Journal of Pure and Applied Chemistry Vol. 3 (6), pp. 102-107

[10] Debbab1, M., El Hajjaji, S., Amal H., Dahchour, A., El Azzouzi1, M., Zrineh, A. (2014) Cypermethrin Residues in Fresh Vegetables: Detection by HPLC and LC-ESIMS and their Effect on Antioxidant Activity
Mater. Environ. Sci. 5 (S1) 2257-2266 ISSN: 20282508

[11] Erhunmwunse, N.O., Dirisu A., and Olomukoro, J.O. (2012) Implications of Pesticide Usage in Nigeria Tropical Freshwater Biology, 201221 (1) 15- 2

[12] Francisco, P. Garcia1, S. Y., Cortés, A., John ,C. G., Alejandra, C. H., and Patricia V. A. (2012) Pesticides: classification, uses and toxicity. Measures of exposure and genotoxic risks Journal of Research in Environmental Science and Toxicology (ISSN: 23155698) Vol. 1(11) pp. 279-293

[13] Frederick, A. A. (2011) Assessment of Pesticide Residues in Vegetables at theFarm Gate: Cabbage (Brassica Oleracea) Cultivation in cape Coast, Ghana Research Journal Environmental Toxicology 5(3) 180-202 ISSN 1819-3420

[14] Geiger, F. (2010) Persistent negative effects of pesticides on biodiversity and biological control potential on European farmland. Basis and Applied Ecology Pesticide Action Network www.paneurope.info

[15] Kithure, J.G.N., Murung J. I., Tum, P. K., Wanjau, R.N., Thoruwa. C.L. (2017) Fate of LambdaCyhalothrin in Kales, Tomatoes and Cabbage from Rural setting in Kenya International Journal of Scientific Research and Innovative Technology ISSN: 2313-3759 Vol. 4 No. 2

[16] Khan, M. S., Mohammad, M. S., Qaisar M., Amjad H. A. and Kehkashan, A. (2011) Assessment of Pesticide Residues on selected Vegetables of Pakistan J. Chem. Soc. Pak., vol. 33, no. 6

[17] Munawar, H. (2013) Quantification of Pesticide Residues in Vegetables by Different Chromatographic Techniques Journal Chromatograph Separation Technique, $\quad 4: 8 \quad$ http://dx.doi.org/10.4172/21577064.1000200

[18] Mohammed, M. A., Elbashier, X. S., Alnail M., Albashir A. S. A.Bashir, H. O. (2016) Effect of Pesticide Residues (Sevin) on Carrot (Daucus carota L.) and Free Nitrogen Fixers (Azotobacter spp) Journal of Agricultural Sciences, 7, 93-99

[19] Mustapha, F. A., Jallow, D. G., Awadh, M. S., Albaho, V. Y., and Nisar A. (2017) Monitoring of Pesticide Residues in Commonly Used Fruits and Vegetables in Kuwait International Journal of Environmental Research and Public Health

[20] Njoku, K. L., Ezeh, C. V., Obidi, F. O., and Akinola, M. O. (2017) Assessment of Pesticide Residue Levels 
in Vegetables sold in some Markets in Lagos State,

Nigeria Journal of Biotech. Vol. 32 (2017) 53 - 60

ISSN: 01891731

[21] Obida, M. G., Stephen, S. H., Goni, A. D., and Victor, O. O. (2012) Pesticide Residues in Bean Samples from Northeastern Nigeria ARPN Journal of Science and Technology ISSN 2225-7217

[22] Odhiambo, J., Owago, S. Q., Xing, X., Zhang, Y., and Muhayimana, A. S. (2007) Residues of Organochlorine Pesticides in Vegetables from Deyang and Yanting Areas of the Chengdu Economic Region, Sichuan Province, ChinaJournal of American Science; 5(4):91-100

[23] Ogah C.O., Tettey, J., Coker, H.B., and AdepojuBello, A.A. (2012) Analysis of Organochlorine pesticide residues in beans from markets in Lagos State, Nigeria West African Journal of Pharmacy 23 (1) $60-68$

[24] Ojemudia, T. I., (2011) Parasitic contamination of Fresh Vegetables Sold In Jos Markets Global Journal of Medical Research volume 11issue 1 version 1.0

[25] Rohan, D., Siddharth, T., and Padmaja, N. (2012) Pesticide residue analysis of fruits and vegetables Journal of Environmental Chemistry and Ecotoxicology Vol. 4(2), pp. 19-28

[26] Zahid, A., Muhammad, S., Ali, S., Mujeeb, R., Soomro, A., Zaib, J., Nazia, R., Zaira P. T., Farheen, S. (2016) Farmers' Perceptions about Effects of Pesticides Use in Vegetables in Taluka Usta Muhammad of Jaffarabad district, Balochistan Journal of Natural Sciences Research ISSN 2224-3186

[27] Zulaihat, A., Bolanle, E. A., Gimba C.E., and Abel, S. A. (2015) Determination of Organochlorine and Pyrethroid Pesticide Residues in Some Vegetables by QuEChERS Method and Gas Chromatography Triple Quadrupole Mass Spectrometry IOSR Journal of Environmental Science, Toxicology and Food Technology (IOSR-JESTFT) e-ISSN: 2319-2402, pISSN: 2319-2399.Volume 9, Issue 6 Ver. III (Jun. 2015), PP 14-20 